\title{
Efficiency of municipal wastewater treatment with membrane bioreactor
}

\author{
Magdalena DOMAŃSKA ${ }^{1) \mathrm{AD}}{ }^{凶}$, Anna BORAL ${ }^{2)}{ }^{\mathrm{BC}}$, Kamila HAMAL $^{3)} \mathrm{BD}^{\text {, }}$ \\ Magdalena KUŚNIERZ ${ }^{4)}$ EF , Janusz LOMOTOWSKI ${ }^{2) A F}$, \\ Paulina PLAZA-OŻÓG BD
}

\footnotetext{
1) orcid.org/0000-0003-3323-7648; Wrocław University of Environmental and Life Sciences, pl. Grunwaldzki 24, 50-323 Wrocław, Poland; e-mail: magdalena.domanska@upwr.edu.pl

${ }^{2)}$ Wrocław University of Environmental and Life Sciences, Wrocław, Poland; e-mail: janusz.lomotowski@upwr.edu.pl

${ }^{3)}$ orcid.org/0000-0001-5301-177; Wrocław University of Environmental and Life Sciences, Wrocław, Poland; e-mail:kamila.hamal@upwr.edu.pl

4) orcid.org/0000-0002-3515-2915; Wrocław University of Environmental and Life Sciences, Wrocław, Poland; e-mail: magdalena.kusnierz@upwr.edu.pl

6) EkoGłog Sp. z o.o.
}

For citation: Domańska M., Boral A., Hamal K., Kuśnierz M., Łomotowski J., Płaza-Ożóg P. 2019. Efficiency of municipal wastewater treatment with membrane bioreactor. Journal of Water and Land Development. No. 41 (IV-VI) p. 47-54. DOI: 10.2478/jwld-2019-0026.

\begin{abstract}
The increasingly stringent requirements for wastewater treatment enforce the adoption of technologies that reduce pollution and minimize waste production. By combining the typical activated sludge process with membrane filtration, biological membrane reactors (MBR) offer great technological potential in this respect. The paper presents the principles and effectiveness of using an MBR at the Głogów Małopolski operation. Physicochemical tests of raw and treated wastewater as well as microscopic analyses with the use of the FISH (fluorescence in situ hybridization) method were carried out. Moreover, the level of electric energy consumption during the operation of the wastewater treatment plant and problems related to fouling were also discussed. A wastewater quality analysis confirmed the high efficiency of removing organic impurities (on average $96 \%$ in case of $\mathrm{BOD}_{5}$ and $94 \%$ in case of COD) and suspension (on average $93 \%$ ).
\end{abstract}

Key words: activated sludge, biological membrane reactors (MBR), electricity consumption, FISH, microfiltration, ultrafiltration

\section{INTRODUCTION}

Biological membrane reactors (MBR) are among the most modern and most dynamically developing wastewater treatment technologies. The MBR process is considered the best available technology. It was used for the first time in the USA in the late 1970s, and in Japan in the early 1980s [WITKOWSKA 2009b]. In Poland, membrane bioreactors were first used on a larger scale in 2013, after the modernization of a wastewater treatment plant in the town of Rowy on the Baltic shore, and in 2015 in Głogów
Małopolski. The MBR technology is a more modern and advanced version of the activated sludge process. The main difference is the replacement of the secondary clarifier, which is typically used in traditional wastewater treatment operations, with a membrane module [KONIECZNY 2015]. Municipal wastewater is treated in bioreactors by ultrafiltration (UF) and microfiltration (MF) membranes with pore sizes of $0.001-0.1$ and $0.1-10 \mu \mathrm{m}$ respectively [LE CLECH et al. 2006]. By applying pressure, the water solution, the solvent, dissolved substances with low molecular weights and colloidal substances permeate the membrane, 
whereas other substances are captured in the reactor [KONIECZNY 2015]. The membrane module can operate as an independent device or as a module submerged in the bioreactor [NG, KIM 2007]. High efficiency characterizes submerged hollow fiber membrane modules, which consist of module heads and bundles of fibers with a length of 1.5-2.0 m. Typically, polyvinylidene fluoride (PVDF) polymer fibers are used, with pore diameter of 0.03-0.04 $\mu \mathrm{m}$. The most frequently used module configuration is the curtain module, which contains 4 to 12 fiber sheets. The filtration process is carried out from the outside to the inside by using light underpressure, which is created by a filtrate pump [SHENG 2011].

Due to the prolonged presence of activated sludge in the reactor, and the stopping of multi-particle compounds by the membrane, it is possible to reduce $\mathrm{BOD}_{5}, \mathrm{COD}$ and some biogenic salts as well as to remove microimpurities that are otherwise resistant to biodegradation, such as pharmaceuticals, pesticides and hormonal substances. This process is favoured by long sludge age, which stimulates the growth of specific, slowly-multiplying bacteria capable of eliminating these compounds [KONIECZNY 2015; WITKOWSKA 2009a].

Compared with conventional activated sludge reactors, membrane bioreactors are characterized by very high efficiency of phase separation, high effluent quality (physicochemical and microbiological), smaller capacity of the reactor due to using higher sludge concentrations, and a smaller amount of surplus sludge [HERMANOWICZ 2011; JUDD, JUDD (eds.) 2011; MELIN et al. 2006]. Moreover, the MBR process causes the physical disintegration of wastewater, which makes it possible to reuse the permeate and increases the efficiency of additional chemical disinfection [GRANT et al. 2012].

High biomass concentration (reaching $35 \mathrm{~g} \cdot \mathrm{dm}^{-3}$ ) obtained in membrane reactors contributes to the effectiveness of wastewater treatment, but simultaneously leads to technical problems. The most important among them is membrane fouling. During the filtration process, sludge forms deposits on the external surface of the membrane, which reduces its efficiency. Fouling is influenced by factors such as the size of sludge flocs, biomass concentration, and the presence of dissolved biopolymer suspension, which is adsorbed on the surface. Biofouling is equally important and difficult to counter. It is caused by the growth of microorganisms within the membranes, which can result in their irreversible damage. Once bacteria deposit on the membrane, they multiply and secrete extracellular polymeric substances (EPS), which are responsible for the formation of biofilms on the membrane surface. The type, rate of growth and amount of microorganisms depends on temperature, $\mathrm{pH}$, the concentration of dissolved oxygen, the presence of sunlight, nutrients and the type of membrane polymer [BODZEK 2012]. Biofouling leads to higher pressure requirements, and consequently higher operating costs [ULMAN et al. 2013].

The aim of this paper was to present the effectiveness of membrane processes on the basis of a wastewater treatment plant in Głogów Małopolski. Samples of raw and treated wastewater, as well as wastewater from the bioreac- tor, were analysed. Tests were carried out to measure chemical pollution, sludge microscopy and the consumption of electric energy. Exploitation problems related to fouling were also discussed.

\section{MATERIALS AND METHODS}

The Membrane Wastewater Treatment Plant in Głogów Małopolski has been designed to accommodate the average daily inflow of $Q_{\mathrm{dav}}=5000 \mathrm{~m}^{3} \cdot \mathrm{d}^{-1}$, maximum $Q_{\mathrm{dmax}}=6000 \mathrm{~m}^{3} \cdot \mathrm{d}^{-1}$, and population equivalent $P E=$ 25000 . Domestic wastewater mixed with some industrial wastewater is irregularly fed to the plant by means of gravitational and pressure sewer systems, and subsequently directed onto the process line to be treated (Tab. 1).

Table 1. Configuration for the biological membrane reactors facility in Głogów Małopolski

\begin{tabular}{|c|c|c|}
\hline \multicolumn{2}{|c|}{ Wastewater management } & \multirow{2}{*}{ Sludge management } \\
\hline mechanical section & biological section & \\
\hline - mechanical bar screen & - SBR chambers & - sludge condenser \\
- wastewater pumping & $(1,2)$ & - dewatering station \\
station & - MBR installation & - installation for pro- \\
- connecting chamber & - permeate tank & cessing sludge into \\
- grit separator & & product \\
\hline
\end{tabular}

Source: own elaboration.

28 samples of raw and treated wastewater were collected on average monthly basis between January 2016 and September 2018, and subjected to physicochemical analyses. The results of tests were shared by the Głogów Małopolski plant, and the subsequent tests were done in the laboratory of Wrocław University of Environmental and Life Sciences. The samples of raw and treated wastewater were also subjected to tests of total organic and inorganic carbon (TOC/TIC). The measurements were made with Sievers InnovOx TOC analyzer. Table 2 shows the methods and norms for the individual parameters for which indicators of pollution were taken.

Table 2. Norms and methods for indicating pollution

\begin{tabular}{|l|c|c|}
\hline Pollution indicator & Research methodology & Norm \\
\hline $\mathrm{BOD}_{5}$ & specific method & PN-EN 1899-1:2002 \\
\hline COD & specific method & PN-ISO 6060:2006 \\
\hline Total suspension & generic method & PN-EN 872:2002 \\
\hline Total nitrogen & by calculation & - \\
\hline Total phosphorus & $\begin{array}{c}\text { spectrophotometry with } \\
\mathrm{HNO}_{3} \text { mineralization }\end{array}$ & PN-EN 1189-2000 \\
\hline Turbidity & nephelometric method & PN-EN ISO 7027:2003 \\
\hline
\end{tabular}

Source: own elaboration.

In order to evaluate the condition of activated sludge at the MBR plant, an additional microscopy of activated sludge was performed for samples collected from the SBR and MBR reactors. First fresh sludge was stained with LIVE/DEAD [Thermo Fisher Scientific undated] reagent in accordance with the producer's protocol, and later the sludge was preserved for further analyses with $4 \%$ paraformaldehyde. 
To analyse the samples with the FISH (fluorescence in situ hybridization) method, Amann's standard protocol was used [AMANN et al. 1995]. The following hybridization probes were used: EUB338 (universal oligonucleotide probe, which covers $90 \%$ members of the domain Bacteria); NSO1225 for identifying AOB (ammonia oxidizing $\beta$-proteobacteria); and PAO462 for identifying polyphosphate-accumulating bacteria, labeled with 6-carboxyfluorescein $(6-F A M)$ dye.

\section{OPERATIONAL CONDITIONS OF THE MBR SYSTEM}

For a membrane filtration system to function correctly, it is necessary to ensure the proper pretreatment. In the water treatment plant under analysis here, pretreatment is carried out by means of a mechanical bar screen and two grit separators, which stop solid debris (rags, sand) and fats. The mechanically treated wastewater gravitationally flows to the sequencing chambers of the bioreactors (SBR 1 and SBR 2), and later is directed onto the MBR installation. Photo 1 shows SBR and MBR reactors. The main operational monitoring items that are checked daily at SBR reactors are: dissolved oxygen, redox potential, activated sludge concentration, $\mathrm{pH}$.

The functioning of the membrane installation is based on automatic, cyclical occurrence of the filtration phase (sucking in wastewater and carrying treated effluent) alternating with the relaxation or backflush phase, which uses

a)

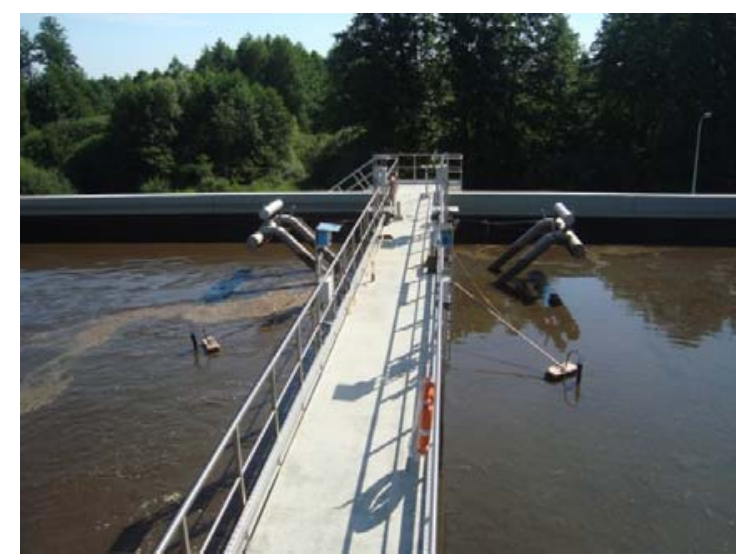

b)

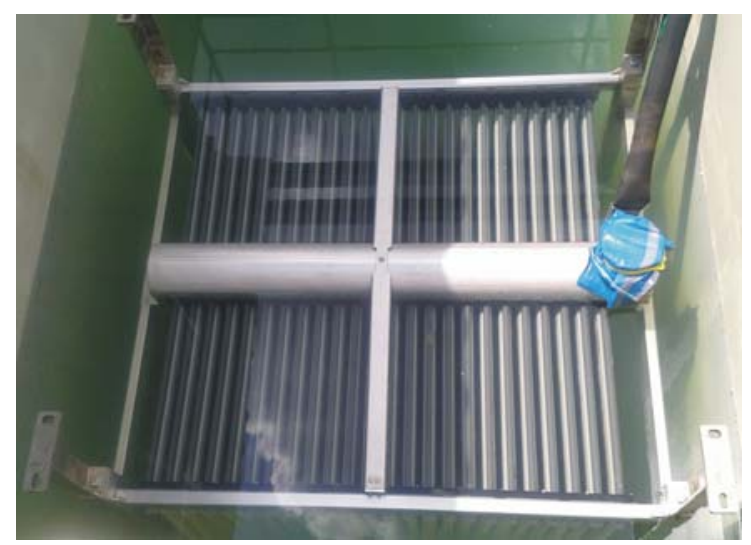

Photo 1. Reactors: a) sequencing batch reactor (SBR), b) membrane bioreactor (MBR) (phot. a) A. Boral, b) M. Domańska) the treated effluent to flush the membranes. Throughout the working time of the membrane installation, it is continuously cleaned by means of intensive aeration and continuous sludge recirculation, which prevents excessive density of sludge in the membrane chamber. The automatic installation periodically initiates a cycle of chemical cleaning of the membranes (with citric acid and sodium hypochlorite), adding small amounts of chemicals during the backflush process. The ultrafiltration system consisting of capillary fibers with pore diameter of $0.04 \mu \mathrm{m}$ ensures efficient separation of effluent and maintains activated sludge concentration at up to more than $10 \mathrm{~g} \cdot \mathrm{dm}^{-3}$. The effluent is subsequently channeled by pressure to the permeate tank, and then gravitationally flows to the reception tank. Concentrated activated sludge is channeled back to the MBR chambers (sludge recirculation). Replacing traditional sedimentation and decantation with an MBR installation ensures that activated sludge is separated from effluent, which practically eliminates suspension in effluent.

\section{RESULTS AND DISCUSSION}

\section{EFFLUENT WATER QUALITY}

The membrane technology reliably removes not only suspended solid ingredients, but also other wastewater pollutants. Table 3 shows the achieved physicochemical parameters of raw and treated wastewater, and the degree of pollutants reduction in the MBR reactor. Statistical analysis confirmed high efficiency of treatment and showed, based on coefficient of variation, that only single probes deviate from the regulations (Table 4). The concentration of total organic carbon for sample from 21 IV 2017 was 71.4 and $11.1 \mathrm{mg} \mathrm{C} \cdot \mathrm{dm}^{-3}$ for raw and treated wastewater respectively. Whereas total organic and inorganic carbon concentration for treated wastewater was $46.2 \mathrm{mg} \mathrm{C} \cdot \mathrm{dm}^{-3}$ and exceeded the regulation established at $30 \mathrm{mg} \mathrm{C} \cdot \mathrm{dm}^{-3}$.

The effectiveness of the analyzed pollutants removal was greater than the requirements specified in the "Order of the Minister of Environment on the conditions to be met when introducing wastewater into water or soil, and on substances particularly harmful to the aquatic environment" [Rozporządzenie... 2014]. In the permeate sample, the total concentration of organic carbon, which measures the amount of organic compounds, was seven times lower than in the raw wastewater and the permeate sample was clear and suspension-free liquid. Turbidity of treated wastewater, based on three analyses, did not exceed 0.7 NTU. As a consequence of low turbidity permeate can be used for technological purposes, which results in water savings.

Comparing the results to the second membrane treatment plant operating in Poland in Rowy, the reduction rate was smaller in Głogów Małopolski WWTP. The average percentage reduction of pollutant loads for sewage treatment plants in Rowy, in summer (with a load of $Q_{d \max }=$ $6369 \mathrm{~m}^{3} \cdot \mathrm{d}^{-1}$ ) for BOD, COD, suspension, total nitrogen and phosphorus was $99,94,99,85$, and $98 \%$ respectively [PIASKOWSKI 2015]. However, it should be taken into account that the results given in the publication refer to the 6-month working period of the treatment plant. 
Table 3. The minimum and maximum values of physicochemical parameters of raw and treated wastewater, requirements and the degree of pollutants reduction after biological membrane reactor filtration

\begin{tabular}{|c|c|c|c|c|c|c|c|}
\hline \multirow{2}{*}{ Pollutant } & \multirow{2}{*}{ Unit } & \multirow{2}{*}{$\begin{array}{c}\text { Raw } \\
\text { wastewater } \\
(\min -\max )\end{array}$} & \multirow{2}{*}{$\begin{array}{c}\text { Treated } \\
\text { wastewater } \\
(\min -\max )\end{array}$} & \multirow{2}{*}{$\%$ of reduction } & \multirow{2}{*}{$\begin{array}{l}\text { Average } \% \\
\text { of reduction }\end{array}$} & \multicolumn{2}{|c|}{$\begin{array}{l}\text { Requirements for treated wastewater }{ }^{1)} \\
(\% \text { of reduction })\end{array}$} \\
\hline & & & & & & $\begin{array}{l}\text { when introducing } \\
\text { into water }\end{array}$ & $\begin{array}{l}\text { when introducing } \\
\text { into soil }\end{array}$ \\
\hline $\mathrm{BOD}_{5}$ & $\mathrm{mg} \mathrm{O}_{2} \cdot \mathrm{dm}^{-3}$ & $22.0-379.0$ & $0.6-15.0$ & 91-99 & 96.0 & 15 & 90 \\
\hline COD & $\mathrm{mg} \mathrm{O}_{2} \cdot \mathrm{dm}^{-3}$ & $375.0-933.0$ & $10.0-134.0$ & $82-99$ & 94.0 & 125 & 75 \\
\hline Suspension & $\mathrm{mg} \cdot \mathrm{dm}^{-3}$ & $55.0-932.0$ & $5.0-20.0$ & $64-99$ & 93.0 & 35 & 90 \\
\hline Total nitrogen & $\mathrm{mg} \cdot \mathrm{dm}^{-3}$ & $27.0-126.2$ & $2.2-43.3$ & $43-97$ & 82.0 & 15 & $70-80$ \\
\hline Turbidity & NTU & $46.0-132.0$ & $0.4-0.7$ & $99.1-99.6$ & 99.4 & - & - \\
\hline
\end{tabular}

${ }^{1)}$ Order of the Minister of Environment on the conditions to be met when introducing wastewater into water or soil, and on substances particularly harmful to the aquatic environment [Rozporządzenie... 2014].

Source: own study.

Table 4. The results of statistical analysis of wastewater physicochemical parameters

\begin{tabular}{|c|c|c|c|c|c|c|c|}
\hline \multirow{2}{*}{ Pollutant } & \multirow{2}{*}{ Unit } & \multicolumn{3}{|c|}{ Raw wastewater } & \multicolumn{3}{|c|}{ Treated wastewater } \\
\hline & & median & $S D$ & $C v(\%)$ & median & $S D$ & $C v(\%)$ \\
\hline $\mathrm{BOD}_{5}$ & $\mathrm{mg} \mathrm{O}_{2} \cdot \mathrm{dm}^{-3}$ & 166.0 & 75.9 & 40.6 & 6.2 & 3.4 & 49.5 \\
\hline COD & $\mathrm{mg} \mathrm{O}_{2} \cdot \mathrm{dm}^{-3}$ & 638.0 & 153.1 & 24.0 & 33.5 & 22.6 & 63.9 \\
\hline Suspension & $\mathrm{mg} \cdot \mathrm{dm}^{-3}$ & 224.0 & 182.9 & 66.3 & 10.0 & 2.8 & 25.8 \\
\hline Total nitrogen & $\mathrm{mg} \cdot \mathrm{dm}^{-3}$ & 62.0 & 21.6 & 33.4 & 9.7 & 7.0 & 67.7 \\
\hline Total phosphorus & $\mathrm{mg} \cdot \mathrm{dm}^{-3}$ & 8.0 & 51.4 & 267.3 & 0.9 & 0.8 & 78.5 \\
\hline
\end{tabular}

Explanations: $S D=$ standard deviation, $C v=$ coefficient of variation

Source: own study.

According to the Order of the Minister of Environment, a certain number of samples may not meet the requirements, but it is sometimes worth considering results that deviate from typical values. The test results confirmed treatment effectiveness at the plant, although in one sample (of 5 VII 2016) it was observed that the concentration of total phosphorus, COD and suspension was higher, while the other parameters were lower, especially $\mathrm{BOD}_{5}(22$ $\mathrm{mg} \cdot \mathrm{dm}^{-3}$, with typical values exceeding $100 \mathrm{mg} \cdot \mathrm{dm}^{-3}$ ). This result significantly influenced statistical analysis, which can be observed in Table 4. The coefficient of variation for total phosphorus was 267.3 and $78.5 \mathrm{mg} \cdot \mathrm{dm}^{-3}$ for raw and treated wastewater respectively, which reflected the heterogeneity of the parameter. Total phosphorus defines the sum of orthophosphates, polyphosphates and organophosphorus compounds, which are released into the environment through the decomposition of living organisms. The concentration of orthophosphates in raw wastewater oscillated between 5.4 and $27.0 \mathrm{mg} \mathrm{P} \cdot \mathrm{dm}^{-3}$, and was within the range typically observed in domestic wastewater [CHMIELOWSKI et al. 2016]. Its concentration rose significantly only in July. The presence of increased phosphorus levels could result from the inflow of rainwater sewage, which was connected with higher concentration of suspension, $\mathrm{COD}$ and $\mathrm{BOD}_{5}$ in the raw wastewater. However, it is more probable that the increase was caused by polyphosphates, which are used in synthetic laundry detergents, among others. The observed elevated levels could be explained by the presence of an industrial facility producing fabric and non-woven fabrics in the proximity. When total phosphorus concentration in raw wastewater reached 285 $\mathrm{mg} \mathrm{P} \cdot \mathrm{dm}^{-3}$, an increased concentration of phosphorus was also observed in treated wastewater. In this case, it is recommended to monitor the inflow of industrial wastewater, in particular in regard to total phosphorus, whose presence could result in increased eutrophication of the reception tank.

\section{CONDITION OF THE ACTIVATED SLUDGE}

An important aspect of the functioning of a water treatment plant is the condition of the activated sludge, which determines the efficiency of the treatment process. To assess it, a microscopy of sludge samples from the SBR and MBR reactors was performed. A majority of organisms from both sources fluoresced green, which indicates high vitality of microorganisms. The sludge was not overgrown with filamentous bacteria, and sludge flocs contained protozoa, which demonstrates good condition of the sludge (Photo 2).

Using the FISH method it was possible to identify AOB bacteria, characteristic for the first nitrification phase (Photo 3) and phosphate-accumulating bacteria (PAO) Photo 4. PAO bacteria accumulate excess phosphorus in the form of polyphosphate in the aerobic conditions. In anoxic conditions phosphorus and nitrogen could be removed simultaneously by one group of heterotrophic microorganisms because PAO bacteria utilize nitrate or nitrite as an electron acceptor instead of oxygen [ŻUBROWSKA-SUdOŁ, CYGANECKA 2008]. While nitrifying bacteria are a common phenomenon in biological wastewater treatment, the presence of PAO bacteria increases the effectiveness of biological phosphorus removal. Lowering phosphorus in treated sewage contributes to reducing the eutrophication of water [GALAS, PIEKARSKA 2013]. Unfortunately, in the sample from 5VII2016 in which the concentration of phosphorus in the raw wastewater was very high, the permeate sample did not meet the requirements either. 

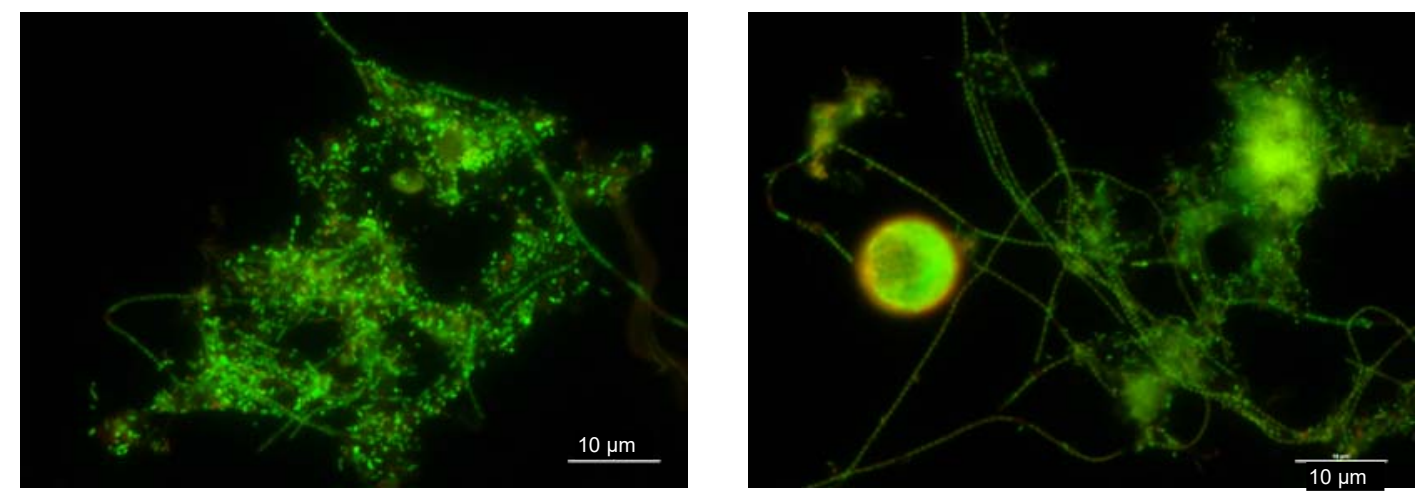

Photo 2. Bacteria from the biological membrane reactor stained with the LIVE/DEAD reagent (phot. M. Domańska)
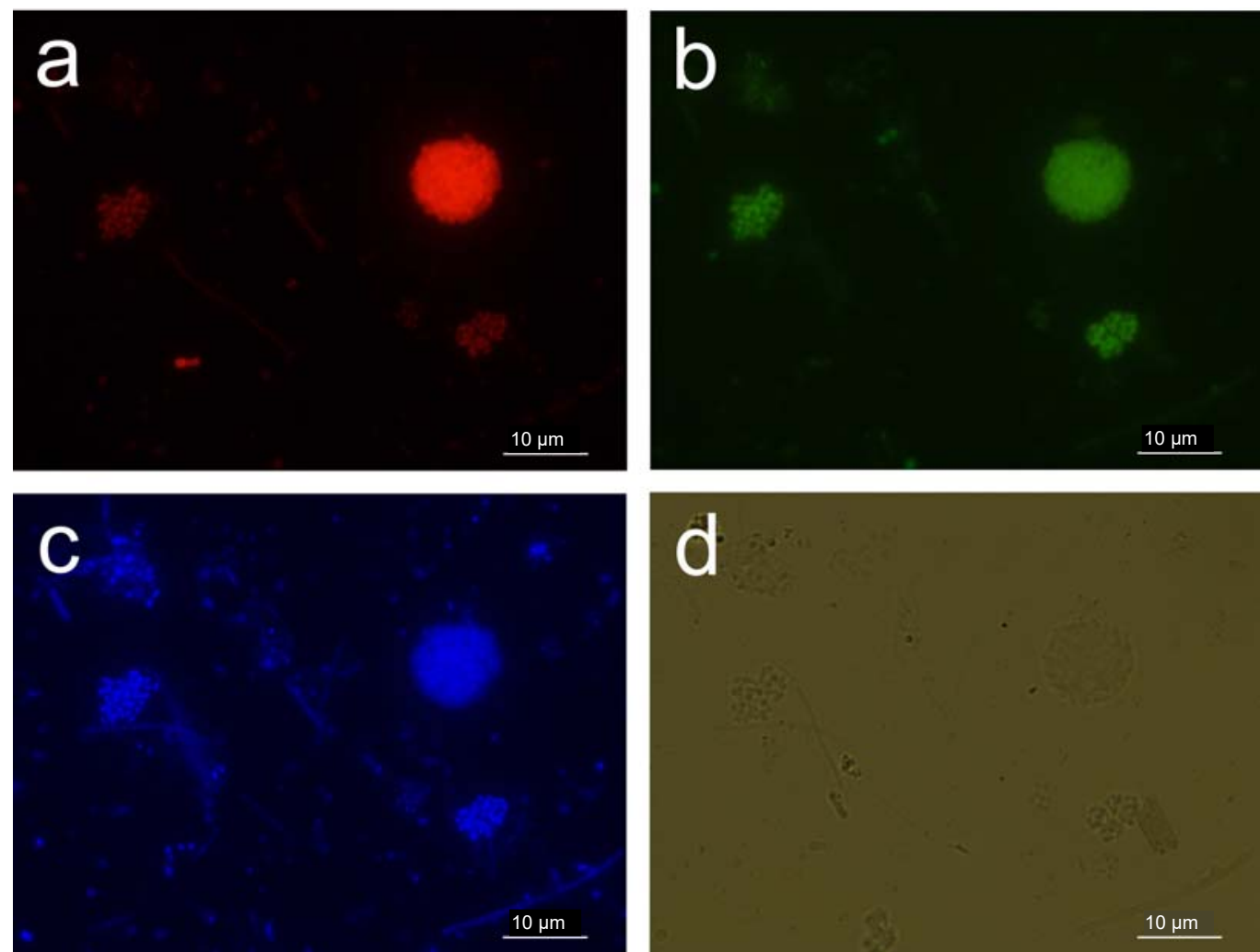

Photo 3. Hybridization of bacteria from the biological membrane reactor by FISH: a) EUB338 probe - all bacteria, b) probe NSO1225 - betaproteobacterial ammonia oxidizing bacteria, c) DAPI, d) Wright field (phot. K. Hamal)
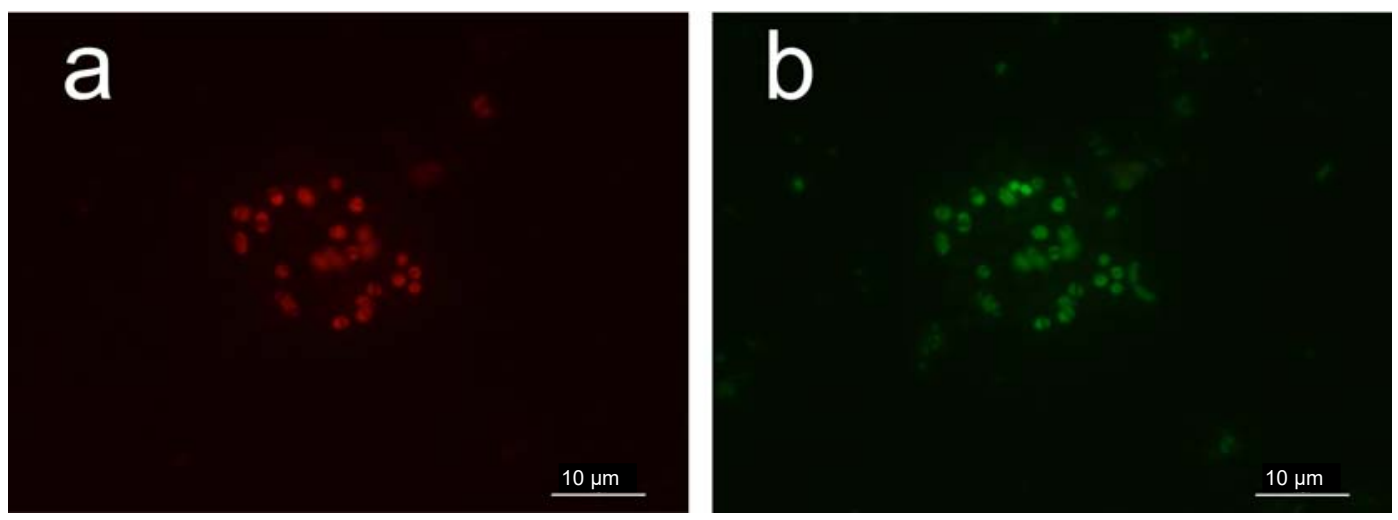

Photo 4. Hybridization of bacteria from the biological membrane reactor by FISH: a) EUB338 probe - all bacteria, b) PAO462 probe - phosphate accumulating bacteria (phot. M. Domańska) 


\section{ELECTRIC ENERGY CONSUMPTION}

The individual consumption of electricity for the operation of the treatment plant depends on many factors, mainly on the aeration process related to the operation of the pumps, choice of treatment technology, extent of automation and membrane used [RIEGER et al. 2012]. In the membrane system using hollow fiber membranes an average $36 \%$ of total energy was used on membrane aeration and $17 \%$ for biology aeration [KRZEMIŃSKI et al. 2012]. According to data concerning municipal MBRs working on a full scale, the average annual electric energy consumption oscillates between: $0.8-2.4 \mathrm{kWh} \cdot \mathrm{m}^{-3}$ in France [BARILLON et al. 2013], $0.8-3.0 \mathrm{kWh} \cdot \mathrm{m}^{-3}$ in Japan [ITOKAWA et al. 2014], 0.4-0.6 $\mathrm{kWh} \cdot \mathrm{m}^{3}$ in China [XIAO et al. 2014], 0.4-1.6 $\mathrm{kWh} \cdot \mathrm{m}^{-3}$ in Spain [GABARRON et al. 2014], $0.8-1.1 \mathrm{kWh} \cdot \mathrm{m}^{-3}$ in the Netherlands [KRZEMIŃSKI et al. 2012] and $0.7-1.8 \mathrm{kWh} \cdot \mathrm{m}^{-3}$ in Germany [PALMOWSKI et al. 2010]. The pollutant load is a very important parameter that determines the consumption of electricity [SAGHAFI et al. 2015]. According to MiZUTA and SHIMADA [2010] specific power consumption $\left(\mathrm{kWh} \cdot \mathrm{m}^{-3}\right)$ decreases with increasing inflow. Therefore, it is difficult to compare small and large wastewater treatment plants only on the basis of the average annual electric energy consumption [SINGH et al. 2012].

An electric energy consumption analysis was performed according to the data registered by controlmeasurement equipment and automatic devices located in the technical room of the Głogów Małopolski wastewater treatment plant. The analysis covered monthly and daily reports from the year 2016. Figure 1 shows the results of electric energy consumption and the amount of treated wastewater for two selected months. In February, $99903 \mathrm{~m}^{3}$ of treated wastewater was produced, whereas in June $57396 \mathrm{~m}^{3}$. Thus producing $1 \mathrm{~m}^{3}$ of treated wastewater required $0.37 \mathrm{kWh}$ and $0.46 \mathrm{kWh}$, respectively.

Comparing to a conventional biological wastewater treatment plant for one of the Lower Silesian wastewater treatment plant with the average daily inflow of $Q_{\text {dav }}=$ $15000 \mathrm{~m}^{3} \cdot \mathrm{d}^{-1}$, electric energy consumption was $0.45-0.55$ $\mathrm{kWh} \cdot \mathrm{m}^{-3}$ in the years $2014-2017$. A comparison with the data concerning the average annual electricity consumption in conventional biological wastewater treatment in Poland and MBR systems in different countries indicates that the Głogów Małopolski installation operates correctly. However, it does not mean that MBR solutions are cheaper than the conventional ones. The full picture could only be obtained by including the cost of exploitation, in particular the cost of cleaning or replacing membranes as well as the consumption of chemicals used for cleaning, which could be calculated only after several years of exploitation.

\section{EXPLOITATION PROBLEMS}

Decreasing efficiency of wastewater treatment and increasing electricity consumption can indicate fouling problems. At the analysed wastewater treatment plant some preventive methods are used. One of the methods for countering biofouling is backflushing, whose frequency varies according to needs. This process is based on flushing permeate in the direction opposite to the regular work of the installation and is integrated with the relaxation phase, during which filtration is stopped to free the membrane from the generated pressure. Moreover, combination of air- and waterflushing solution is used. Another method is chemical cleaning, which uses citric acid and sodium hypochlorite. Chemical cleaning is very efficient, but its frequent and intensive use reduces the lifespan of the membrane [KRZEMIŃSKI et al. 2017]. In order to limit this effect, the capillaries float freely in the wastewater and are cyclically cleaned with a stream of air blown from underneath the membrane.

The problem of membranes fouling appeared at the wastewater treatment plant in Głogów Małopolski after 3 years of exploitation, despite a number of operations for the maintenance of a good efficiency system (Photo 5a). Decreasing flux was the reason for taking the manual

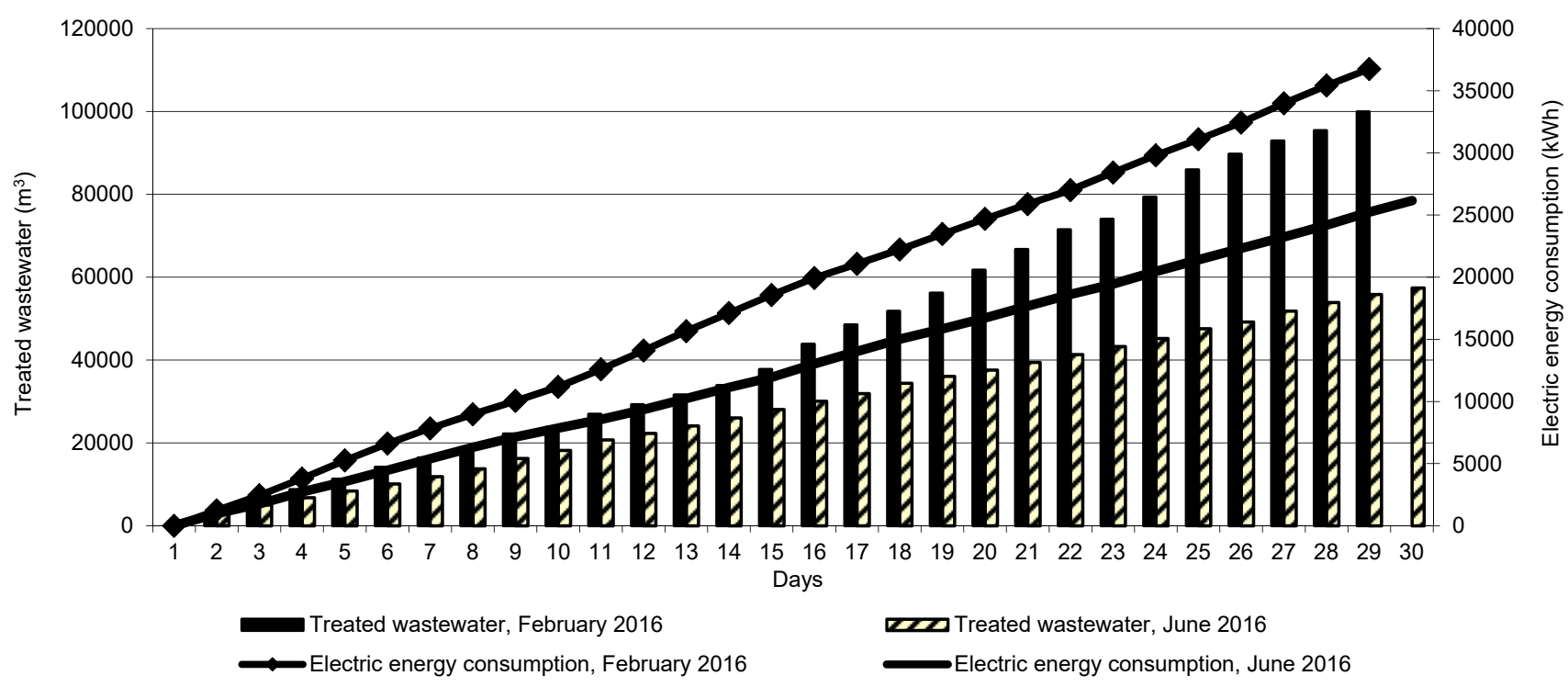

Fig. 1. Monthly production of treated wastewater and electric energy consumption at the membrane treatment plant in Głogów Małopolski in February and June 2016; source: own study 
cleaning process. This process was time-consuming, due to the need to remove the sediment from each fiber separately. After the cleaning process, some fibers were changed colors (Photo 5b) and some were damaged because of the fine structure of the membrane layer (Photo $5 \mathrm{c}$ ). It can be concluded that after the manual cleaning process the performance of the membranes decreases. In addition, during the cleaning period the MBR reactor must be taken out of service. Depending on the condition of the membranes, after approx. 7 years of operation, membrane replacement is required. Replacement of one fiber sheet is about 3 thous. EUR. Considering that the presented system consists of 48 cassettes the purchase of new membranes generates huge costs.

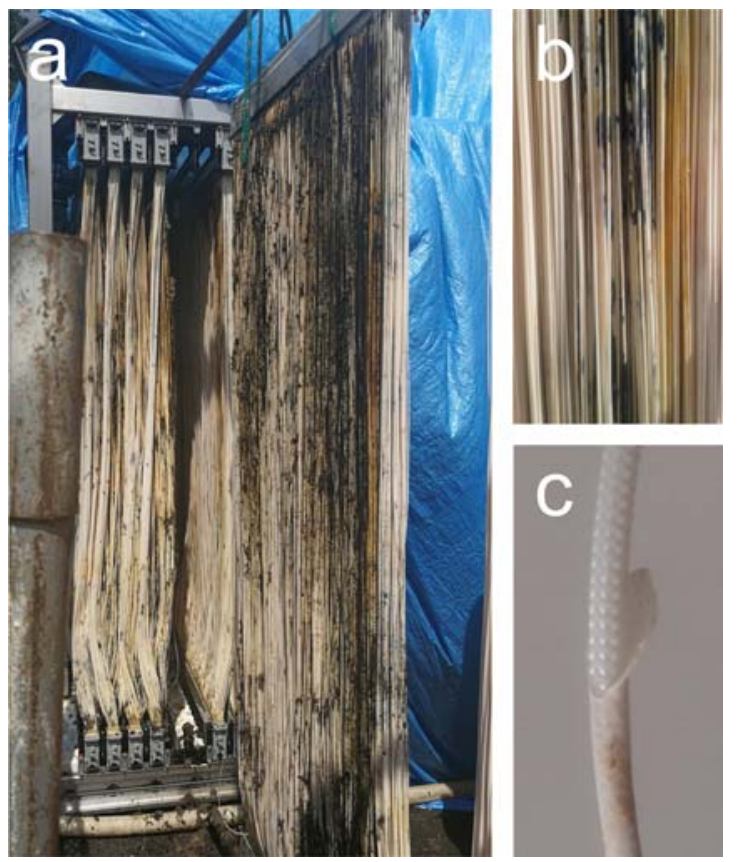

Photo 5. Membranes: a) before cleaning, b) after cleaning, c) visible damage to some fibers (phot. a) M. Kuśnierz,

$$
\text { b), c) M. Domańska) }
$$

\section{CONCLUSIONS}

The MBR technology is an efficient solution that does not entail high energy consumption in comparison with traditional installations. The conducted research indicates high efficiency of domestic wastewater treatment, although the concentration of nitrogen and phosphorus compounds in industrial wastewater should be closely monitored.

Using membrane bioreactors on a wider scale is limited by the exploitation cost of the membrane modules. Despite constant improvements and changes, challenges are still posed by aspects pertaining to production stability as well as efficient and energy-saving procedures of cleaning membranes due to their fouling.

\section{ACKNOWLEDGMENTS}

Publication supported by the Polish Ministry of Science and Higher Education as a part of the program of activities disseminating science from the project "Organization of the First International Science Conference - Ecological and Environmental Engineering", 26-29 June 2018, Kraków.

\section{REFERENCES}

AmanN R.I., Ludwig W, SchleIFER K.H. 1995. Phylogenetic identification and in situ detection of individual microbial cells without cultivation. Microbiological Reviews. Vol. 59(1) p. 143-69.

Barillon B., Ruel S.M., Langlais C., Lazarova V. 2013. Energy efficiency in membrane bioreactors. Water Science Technology. Vol. 67 p. 2685-2691.

BoDzeK M. 2012. Separacja membranowa w inżynierii środowiska. Podstawy procesów. Cz. V [Membrane separation in environmental engineering: Background of the processes. P. V]. Technologia Wody. Nr 5 p. 24-28.

ChMielowski K., BugajSKi P., KaCzor G.B. 2016. Comparative analysis of the quality of sewage discharged from selected agglomeration sewerage systems. Journal of Water and Land Development. No. 30 p. 35-42. DOI 10.1515/jwld-2016-0019.

Gabarron S., Ferrero G., Dalmau M., Comas J., RodriguezRoDA I. 2014. Assessment of energy-saving strategies and operational costs in full-scale membrane bioreactors. Journal of Environmental Management. Vol. 134 p. 8-14.

Galas E., PieKarska K. 2013. Biologiczne usuwanie fosforu ze ścieków. W: Interdyscyplinarne zagadnienia $\mathrm{w}$ inżynierii i ochronie środowiska [Phosphorus removal from wastewater. In: Interdisciplinary problems in environmental protection and engineering]. T. 3. Ed. T.M. Traczewska. Wrocław. Ofic. Wydaw. PWroc. p. 163-169.

Grant S.B., Saphores J.D., Feldman D.L., Hamilton A.J., Fletcher T.D., CoOK P.L., Stewardson M., SANDERS B.F., Levin L.A., Ambrose R.F., Deletic A., Brown R., Jiang S.C., Rosso D., CoOper W.J., Marusic I. 2012. Taking the "waste" out of out of "wastewater" for human water security and ecosystem sustainability. Science. Vol. 337 p. 681-686.

HeRmanOwICZ S.W. 2011. Membrane bioreactors: Past, present and future? [online]. UC Berkeley: Water Resources Collections and Archives. [Access 01.03.2018]. Available at: https://escholarship.org/uc/item/9293s8zw

Itokawa H., TsujI K., Yamashita K., Hashimoto T. 2014. Design and operating experiences of full-scale municipal membrane bioreactors in Japan. Water Science and Technology. Vol. 69 p. 1088-1093.

JUDD S., JUDD C. (eds.) 2011. The MBR book. Principles and applications of membrane bioreactors for water and wastwater treatment. 2nd ed. Elsevier. ISBN 9780080966823 pp. 536.

KonieCZNY K. 2015. Efektywność oczyszczania ścieków przy zastosowaniu reaktora membranowego [Effectiveness of wastewater treatment with the use of the biological membrane reactors]. Rocznik Ochrona Środowiska. Vol. 17 p. 1034-1052.

KrZemiński P., LeVerette L., Malamis S., Katsou E. 2017. Membrane bioreactors - A review on recent developments in energy reduction, fouling control, novel configurations, LCA and market prospects. Journal of Membrane Science. Vol. 527 p. 207-227.

KRZEMIŃSKi P., VAN DER GRAAF J.H.J.M., vAN LIER J.B. 2012. Specific energy consumption of membrane bioreactor (MBR) for sewage treatment. Water Science and Technology. Vol. 65 p. $380-394$.

Le Clech P., Chen V., Fane T.A.G. 2006. Fouling in membrane bioreactors used in wastewater treatment. Journal of Membrane Science. Vol. 284 p. 17-53.

Melin T., JefFerson B., BiXio D., Thoeye De Wilde W., De KONING J., VAN DER GRAAF J., WinNTGENS T. 2006. Membrane bioreactor technology for wastewater treatment and reuse. Desalination. Vol. 187 p. 271-282.

MizuTA K., SHimadA M. 2010. Benchmarking energy consumption in municipal wastewater treatment plants in Japan. Water Science and Technology. Vol. 62(10) p. 2256-2262. 
NG A. N.L., KIM A.S. 2007. A mini-review of modeling studies on membrane bioreactor (MBR) treatment for municipal wastewaters. Desalination. Vol. 212 p. 261-281.

Palmowski L., Veltmann K., Pinnekamp J. 2010. Energy optimization of large-scale membrane bioreactors - Importance of the design flux. In: Water energy interaction of water reuse. Eds. V. Lazarova, K. Choo, P. Cornel. London. IWA Publ. p. 139-148.

PIASKOWSKI K. 2015. Oczyszczanie ścieków komunalnych w bioreaktorach membranowych na przykładzie oczyszczalni ścieków w Rowach [Example of municipal wastewater treatment in membrane bioreactor in Rowy]. Gaz, Woda i Technika Sanitarna. Nr 3 p. 113-118.

PN-EN 872:2002. Jakość wody - Oznaczanie zawiesin - Metoda z zastosowaniem filtracji przez sączki z włókna szklanego [Water quality - Determination of suspended solids by filtration through glass-fibre filters].

PN-EN 1189-2000. Jakość wody - Oznaczanie fosforu - Metoda spektrofotometryczna z molibdenianem amonu [Water quality - Determination of phosphorus - Spectrophotometric method with ammonium molybdate].

PN-EN 1899-1:2002. Jakość wody - Oznaczanie biochemicznego zapotrzebowania tlenu po n dniach (BZTn) - Część 1. Metoda rozcieńczania i szczepienia z dodatkiem allilotiomocznika [Water quality - Determination of biochemical oxygen demand after $\mathrm{N}$ days (BODn) - Part 1. Method for undiluted samples].

PN-EN ISO 7027:2003. Jakość wody - Oznaczanie mętności [Water quality - Determination of turbidity].

PN-ISO 6060:2006. Jakość wody - Oznaczanie chemicznego zapotrzebowania tlenu [Water quality - Determination of the chemical oxygen demand].

RIEGER L., TAKÁCS I., SIEgRIST H. 2012. Improving nutrient removal while reducing energy use at three Swiss WWTPs Using Advanced Control. Water Environment Research. Vol. 84(2) p. 170-188.

Rozporządzenie Ministra Środowiska z dnia 18 listopada 2014 r. w sprawie warunków, jakie należy spełnić przy wprowadzaniu ścieków do wód lub do ziemi, oraz w sprawie substancji szczególnie szkodliwych dla środowiska wodnego [Order of the Minister of Environment of 18. November 2014 on conditions to be met when introducing of sewage into the water or ground and on substances particularly harmful to the aquatic environment]. Dz. U. z 2014 poz. 1800.

Saghafi S., Mehrdadi N., Hendy G. N.B., Rad H.A. 2015. Energy efficiency in wastewater treatment plant emphasizing on COD removal: A case study of Amol Industrial Zone, Iran. Canadian Journal of Pure and Applied Sciences. Vol. 9(2) p. 3441-3448.

SHENG C. 2011. Application of submerged hollow fiber membrane in membrane bioreactors: Filtration principles, operation, and membrane fouling. Desalination. Vol. 283 p. 31-39.

Singh P., Carliell-Marquet C., Kansal A. 2012. Energy pattern analysis of a wastewater treatment plant. Applied Water Science. Vol. 2 p. 221-226.

Thermo Fisher Scientific undated. LIVE/DEAD cell viability assays [online]. [Access 01.03.2018]. Available at: https://www.thermofisher.com/us/en/home/brands/molecularprobes/key-molecular-probes-products/live-dead-viabilitybrand-page.html

Ulman E., Pitrus K., ANielaK A.M. 2013. Zastosowanie i problemy eksploatacyjne nanofiltracji i ultrafiltracji [Application and operating problems of nanofiltration and ultrafiltration]. Technologia Wody. Nr 7-8 p. 27-28.

WITKOWSKA E. 2009a. Biologiczne reaktory membranowe (MBR) - nowa technologia oczyszczania ścieków z wykorzystaniem osadu czynnego [Biological membrane reactors (MBR) - a new technology of wastewater treatment using activated sludge]. Forum Eksploatatora. Nr 3 p. 28-30.

WiTKOWSKA E. 2009b. Usuwanie azotu w biologicznych reaktorach membranowych (MBR) - doświadczenia zagraniczne $\mathrm{i}$ badania własne [Nitrogen removal in biological membrane reactors (MBR) - foreign experiences and own research]. Gaz, Woda i Technika Sanitarna. Nr 7-8 p. 37-40.

Xiao K., Xu Y., Liang S., Lei T., Sun J., Wen X., Zhang H., Chen C., Huang X. 2014. Engineering application of membrane bioreactor for wastewater treatment in China: Current state and future prospect. Frontiers of Environmental Science and Engineering. Vol. 8 p. 805-819.

Żubrowska-SudoŁ M., CyganeCKa A. 2008. Proces defosfatacji denitryfikacyjnej, jako alternatywna metoda usuwania ze ścieków związków biogennych [Denitrifying dephosphatation as an alternative solution for nutrient removal from wastewater]. Biotechnologia. Vol. 1. Nr 80 p. 136-145.

\section{Magdalena DOMAŃSKA, Anna BORAL, Kamila HAMAL, Magdalena KUŚNIERZ, Janusz ŁOMOTOWSKI, Paulina PLAZA-OŻóG}

\section{Efektywność oczyszczania ścieków komunalnych na przykładzie bioreaktora membranowego}

\section{STRESZCZENIE}

Wraz ze wzrostem wymagań stawianym ściekom oczyszczonym wdrażane są technologie umożliwiające dużą redukcję zanieczyszczeń i jednocześnie małą produkcję odpadów. Biologiczne reaktory membranowe (MBR) dzięki połączeniu klasycznego procesu osadu czynnego z membranową filtracją ścieków stwarzają duże możliwości technologiczne. W pracy przedstawiono zasadę działania oczyszczalni pracującej w Głogowie Małopolskim oraz efektywność jej działania. Wykonano analizę fizykochemiczną ścieków surowych i oczyszczonych oraz analizę mikroskopową z wykorzystaniem metody FISH (fluorescence in situ hybridization), a także przedstawiono poziom zużycia energii elektrycznej podczas pracy oczyszczalni oraz omówiono problemy związane z zarastaniem membran. Analiza jakości ścieków potwierdziła wysoką skuteczność usuwania zanieczyszczeń organicznych (średnio $96 \% \mathrm{w}$ przypadku BZT $_{5}$ i $94 \% \mathrm{w}$ przypadku ChZT) oraz zawiesiny ('średnio 93\%).

Slowa kluczowe: biologiczne reaktory membranowe (MBR), FISH, mikrofiltracja, osad czynny, ultrafiltracja, zużycie energii elektrycznej 